УДК 94(479.24)

Научная статья

DOI 10.18101/2306-630X-2020-1-38-45

\title{
ХАЗАРСКИЙ КАГАНАТ ОТ КАСПИЯ ДО ВОСТОКА (600-1000 гг.)
}

\author{
(C) Аласов Имамаддин Фарман оглы \\ выпускник аспирантуры, \\ Ярославский государственный университет им. П. Г. Демидова \\ Россия, 150003, г. Ярославль, ул. Советская, 14 \\ alasov_imam@mail.ru
}

\begin{abstract}
Аннотация. В статье показаны народы Хазарского каганата с учетом Азербайджана, занимающего центральную позицию в геополитике по отношению прикаспийских стран на континенте. Хазары относились к тюркоязычным народам, где в VII в. смогли создать крупнейшее торговое государство на континенте, что являлось главной их целью, преследуя прежде всего экономические интересы, подчиняя себе юг России и восток Украины, Крымский полуостров, часть Узбекистана и Казахстана. Отличительной особенностью с учетом цели Хазарского каганата являлась веротерпимость, а также стремление к справедливости среди стран мира, в то время как в Европе гораздо жестче относились к этим вопросам. Все преследуемые за убеждения устремились в Хазарский каганат. Он рассматривается как один из ключевых имперских политических игроков на континенте с 600 до 1000 г. н. э., от которого зависела геоэкономическая и геополитическая стабильность всей Евразии. Распад Хазарского каганата повлек за собой образование новых государств, в том числе и Руси, а также больше геополитических проблем.

Ключевые слова: Хазарский каганат; Азербайджан; Русь; Каспийское - Хазарское море; страны Средней Азии.
\end{abstract}

\section{Для цитирования}

Аласов И. Ф. Хазарский каганат от Каспия до Востока (600-1000 гг.) // Евразийство и мир. 2020. № 1. С. 38-45.

Хазарский каганат в историческом, политическом, культурном и географическом отношении имеет прямое отношение к Каспийскому морю (Xəzər dənizi). Средневековое «имперское» государство Хаза́рский кагана́т (Хаза́рия) (650-969), созданное кочевыми народами - хазарами, с учетом Западно-Тюркского каганата, сумело сформировать развитую систему государственного устройства, процветающую торговлю и постоянную армию [18, с. 19]. Особенностью Хазарского каганата являлась веротерпимость, а также стремление к справедливости среди стран мира, в то время как в Европе гораздо жестче относились к этим вопросам. Люди, преследуемые за религиозные убеждения, устремились в Хазарский каганат. История Хазарского каганата уходит в глубь раннего средневековья, когда на Руси и на юге страны жили разные тюркские племена - хазары. Хəzər Dənizi - отсюда берет свое начало название «Каспийское море» на азербайджанском языке. Хазарским также назывались Азовское и Черное моря из-за живших вокруг побережья хазарских племен. До XVI в. название «Хазария» в византийских и итальянских источниках дольше всего сохранилось за Северным Причерноморьем, а Крым называли Хазарией вплоть до XV-XVI вв. [12]. 
O хазарах стало известно еще со времен Империи гуннов, IV-V вв. н.э., в период становления великого Тюркского каганата ${ }^{1}$. Они поддержали Истеми-кагана и участвовали в походе на Грузию и Азербайджан. Хазары, появившись впервые в Европе в 463 г., говорили на одном из ранних тюркских языков, принадлежащих к огузской группе [7, с. 92].

Основу Хазарского каганата составляли тюркоязычные народы - огу́зы (тур. и азерб. Oğuzlar), c IV по XI в. жившие на Кавказе, а потом, уже в VII в., на территории части Средней Азии сумели создать крупнейшее торговое государство. За столетия они расширили свое господство, подчинив себе юг России (Краснодарский край, Ставропольский край, Республика Калмыкия, с учетом всего Северного Кавказа, и часть Украины) и всю прибрежную сторону Черного и Азовского морей [7, с. 92].

В состав Хазарского каганата прежде всего входили народы (племена) - хазары, волжские булгары, русы Восточной Европы и Сибири. Хазарский каганат по географическому положению охватывал восток - запад, соединяющий Дальний Восток и Византию, север - юг, соединяющий славянские племена. Хазары до V в. были частью Гуннской державы и назывались акациры ${ }^{2}$, которые были упомянуты византийским историком Приском Панийским.

Еще в середине VI в. хазары были под властью Западно-Тюркского каганата, и спустя ровно сто лет каганат распался. Хазары, набирая опыт у Тюркского каганата, основали свой каганат, покорив некоторые соседние булгарские, кавказские и славянские племена - от Кавказа по юго-восточной части Сибири (якуты), начиная по обе стороны Среднего и Южного Урала от Поволжья (Татарстан, Чувашия), включая Приобье (Ханты-Мансийский автономный округ), составляя северо-западную часть обширного тюркского этнокультурного пространства [8].

В результате длительных гражданских войн могущественный Тюркский каганат распался на две части - Западно-Тюркский (603-658) и Восточно-Тюркский (с учетом II Восточно-Тюркского каганата, 603-744), при этом избегая кровавых междоусобиц, окреп и даже смог угрожать существованию Китая, в результате после третьего этапа войны Китай был завоеван [5, с. 93-108].

Хазарский каганат выделился из Западно-Тюркского каганата, преследуя булгар, устремился на запад. В письме Хазарского кагана Иосифа, сына Хазарского царя Аарона II из династии Буланидов, говорится, что «хазары преследовали булгар до самого Дуная». К концу VII в. власть Хазарского кагана распространилась на все Северное Причерноморье, включая большую часть Крыма. «Хазары, великий народ... овладели всей землей вплоть до Понтийского моря», — пишет византиец Феофан. Империи удалось отстоять один Херсонес, который, впрочем, на время потерял всякое экономическое значение. Папа Мартин I (умер в 656 г.), сосланный в Херсонес, в письмах жаловался на недостаток и дороговизну продуктов в этом городе, некогда снабжавшем хлебом Византию» [13].

В 652-653 гг. произошло первое крупное сражение хазар с арабами около города Баланджар, где хазарам пришлось остановить атаку захватчиков и арабский

\footnotetext{
${ }^{1}$ После распада в V в. Империи гуннов основу составляли алтайские тюрки.

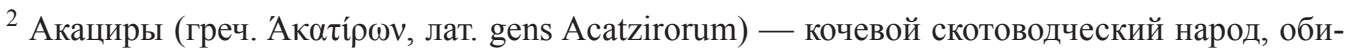
тавший в III-IV вв. на территории Европы — от Приднепровья до Восточной Прибалтики и верховий Волги.
} 
полководец Салман ибн Раби был убит. Однако постоянные атаки арабов против хазар в итоге вынудили их уйти на север Кавказа. Тем не менее хазары практически блокировали экспансию халифата на север в Восточную Европу.

Первой столицей Хазарского каганата до 720 г. был Беленджер, один из средневековых городов на территории прикаспийского азербайджанского Дербента, а потом хазары перенесли свою столицу в Семендер. Даже порой жители Персии строили себе жилье и иные исторические крепостные стены только с разрешения Хазарского каганата, чтобы укрыться от неожиданных нападений хазар. Глобальная оборонительная система Сасанидского Ирана и народов Хазарского каганата служила своего рода границей между оседло-земледельческим и скотоводческим миром, плотиной для удержания кочевнических волн в Евразии [15, с. 37-47].

После поражения, понесенного хазарами от арабов в 737 г., столица Хазарского каганата была перенесена из Семендера в Итиль, удаленную от военных действий дельту Волги. Итиль (Атиль) — столица Хазарского каганата (середина VIII в. $\mathrm{X}$ в.), оказалась очень удобной в торговом отношении, что позволяло контролировать выход в Каспийское море. Итиль был портовым городом Хазарского каганата, a c середины VIII в. начался подъем международной торговли и город превратился в крупнейший рынок.

Исторически Кавказ всегда считался значимым экономическим регионом для трех мировых держав - Византийской империи, Персидской империи и Хазарского каганата, практически каждая из них пыталась установить контроль.

Одним из таких исторических ожесточенных периодов является столетняя война за Кавказ между двумя восточными державами того времени - Исламским халифатом и Хазарским каганатом. Особо следует отметить военную борьбу, когда при халифе Умаре бин аль-Хаттабе войска мусульман вошли впервые на территорию Кавказа. Поэтому, исходя из экономических интересов, Хазарский каганат контролировал важнейшие узловые пункты маршрутов Шелкового пути, добиваясь большой экономической прибыли от торговли и транзита, а также облагая данью в том числе и восточнославянские народы.

Еще в VIII в. в городе Итиль, столице могущественного тогда Хазарского каганата, существовали целые слободы русских купцов, которые вели торговлю со странами Кавказа. Сведения арабских путешественников и географов IX-X вв. свидетельствуют, что русские купцы спускались по Волге в прикаспийские области, добираясь до Багдада. И позже, в годы господства Золотой орды, русские суда появлялись на Каспийском море, русские купцы торговали на Кавказе и в Азербайджане. В 1465 г. между Великим княжеством Московским и государством Ширваншахов (существовало в IX-XVI вв.) были установлены дипломатические отношения.

Кроме огузов - тюркоязычных народов, население Хазарского каганата на Кавказе составляли мелкие бейлербеи ${ }^{1}$ и еврейские общины. В свою очередь в Приуралье жили мадьяры (венгры), а за Уралом в основном кочевали гузы ${ }^{2}$, печенеги (тюрки)

\footnotetext{
${ }^{1}$ Бейлербей (беглярбек, беглербег) (от тур. Beylerbeyi, букв. бек всех беков) - чиновник высокого ранга, наместник в мусульманских государствах в Средние века и Новом времени: в Сельджукской империи.

${ }^{2}$ Гузы - средневековые тюркские племена, предки современных турок, азербайджанцев, гагаузов и туркмен.
} 
также составляли часть Хазарского каганата. С учетом разных менталитетов народов взаимоотношения между этими государствами были довольно сложными. Долгое время над болгарами правила тюркская династия Дуло, а над хазарами - династия Ашина, и династии враждовали между собой [20, s. 55-56].

С другой стороны, иранские сельджуки ${ }^{1}$, которые составляли одну ветвь огузов, к концу XI в. контролировали империю, простиравшуюся от Амударьи до Персидского залива и от реки Инда до Средиземного моря [3, с. 434].

Ряд отечественных историков Хазарский каганат отмечал как забытую империю на территории России. Русский ученый историк В. Григорьев в своей заметке об устройстве власти в Хазарском каганате писал, что хазары- это феномен средневековья.

Следует обратить внимание на труды советского академика Б. Рыбакова о Хазарском каганате, об их отношении к другим народам и государствам, только преследуя свои экономические интересы в виде установления платы данью, с учетом их веротерпимости и справедливости. В 1953 г. в журнале «Советская археология» академик Б. Рыбаков в статье «К вопросу о роли Хазарского каганата в истории Руси» характеризовал великий Хазарский каганат абсолютно уничижительно: «Примитивное государство кочевников-хазар, долгое время существовавшее лишь благодаря тому, что превратилось в огромную таможенную заставу, запиравшую пути по Северному Донцу, Дону, Керченскому проливу и Волге» [19, с. 117].

У большинства российских историков сложилась разная позиция относительно Хазарского каганата, его влияния на другие государства. Есть противоположное мнение: крупнейший исследователь-востоковед Л. Гумилев, тщательно проанализировав имевшуюся совокупность исторических фактов, пришел к выводу, что «Хазарское государство почти целый век господствовало над Русью и определяло всю ее политику, что судьба Хазарии - тюркской державы, расположенной между нижней Волгой и Доном и принявшей в VIII в. иудаизм как господствующую религию», до последних десятилетий рассматривалась как чисто академическая тема. Положение изменилось, когда в 1951 г. в «Правде» появилась статья никому не известного П. Иванова, где осуждались работы историков, которым присуще «непонятное любование хазарской культурой» [11, с. 9].

Основным ремеслом для хазар было занятие сельским хозяйством, торговлей, что позволило им впоследствии развиться в сильную торговую державу, и они всегда были верхом на лошади - всадниками. Благодаря торговле и дани в виде взыскиваемых пошлин с караванов, проходивших через Шелковый путь, Хазарский каганат разбогател.

Русский историк-востоковед В. Григорьев, занимавшийся историей Хазарского каганата, в одном из своих трудов отмечал, что «необыкновенным явлением в Средние века был народ хазарский. Окруженный племенами дикими и кочующими, он имел все преимущества стран образованных: «устроенное правление, обширную, цветущую торговлю и постоянное войско (подчеркнуто нами. - И. Ф.). Когда величайшее безначалие, фанатизм и глубокое невежество оспаривали друг у друга

\footnotetext{
${ }^{1}$ Сельджу́ки - ветвь огузо-туркменского племени кынык (гынык), принадлежавшая к центральноазиатским тюркам.
} 
владычество над Западной Европой, держава хазарская славилась правосудием и веротерпимостью, и гонимые за веру стекались в нее отовсюду. Как светлый метеор, ярко блистала она на мрачном горизонте Европы и погасла, не оставив никаких следов своего существования» [9].

В 1954 г. М. Артамонов, специально занимавшийся Хазарией, признал, что «выступление «Правды» сыграло положительную роль: оно обратило внимание на бесспорную идеализацию хазар в буржуазной науке и на преувеличение их значения в образовании русского государства». Он утверждал, что роль Хазарии в истории была двойственной: до принятия иудаизма она «была прогрессивной», но «принятие иудейской религии было для них роковым шагом» [1, с. 27].

Самым важным из факторов усиления Хазарского каганата был конфликт с Арабским халифатом. Праведный халиф Умар ибн аль-Хатта́б аль-Фарук ${ }^{1}$ (государственный деятель, 634-644 гг.) отдал приказ своим войскам выступить на Кавказ. С другой стороны, благополучные отношения сложились у хазар с Византийской империей [16, с. 67].

Известно, что в VII в. каганат участвовал на стороне византийского императора Ираклия против сасанидов, это ирано-византийская война 602-628 гг. ${ }^{2}$, которую Л. Гумилев назвал «мировой войной VII в.» [10]. Еще в свое время византийские императоры Константин V и Юстиниан II взяли себе хазарских жен, так как Византия была заинтересована в Хазарском каганате. Ведя активную торговую деятельность, хазары, безусловно, знали о существовании христианства, ислама и других религий, но особого предпочтения не отдавали ни одной из религий. Соответственно, еще до принятия ислама у народа Хазарского каганата правящей религией был иудаизм³.

Изначально хазары - тюркоязычное племя - этнически не были евреями, и в VII в. они образовали Хазарский каганат на западных осколках Тюркского каганата. На рубеже VIII-IX вв. хазарские правящие круги приняли иудаизм. После этого в Хазарию перебралось немало евреев, признававших новообращенных иудеев «за своих». До этого у хазар не было официальной религии. Под влиянием Византии и Халифата в государстве, на удивление, мирно уживались христианство и ислам. Иудаизм помог усилить позиции в Дагестане, где проживало много еврейских общин. С принятием иудаизма в каганате установилась система двойного правления, когда территориями правили беки, а во главе их оставался каган. С другой стороны, каганат останавливал потоки кочевников из Азии в Европу.

\footnotetext{
${ }^{1}$ Умар ибн аль-Хаттаб вначале (вплоть до VI в. от начала пророчества) был ярым противником ислама и мусульман, но со временем пересмотрел взгляды на ислам под влиянием своей сестры, которая дала ему прочесть Коран, и изьявил желание встретиться с Мухаммедом.

${ }^{2}$ Ира́но-византи́йская война́ 602-628 гг. — последняя война между Византийской империей и империей Сасанидов, длившаяся 26 лет.

${ }^{3}$ Ислам возник в начале VII в. в Западной Аравии, в Мекке. Вместе с иудаизмом он относится к так называемым «авраамическим религиям», ревелятивной (богооткровенной) традиции. Ислам / Т. К. Ибрагим // Новая философская энциклопедия: в 4 т. / пред. науч.-ред. совета В. С. Стёпин. 2-е изд., испр. и доп. М.: Мысль, 2010.2816 с.
} 
Учитывая наибольшую численность азербайджанцев в Иране на современном этапе по отношению к другим этносам Кавказского - Каспийского - Черноморского побережья, основными обитателями Хазарского каганата были «азербайджанские тюрки» [17, с. 576-578].

Тюркский каганат - гунны состояли в родственных отношениях с Хазарским каганатом, которые поддерживали друг друга на политической арене. В свою очередь племенное объединение печенегов кочевало в заволжских степях северо-восточнее хазар между мадьярами, кипчаками и огузами.

По летописной версии, первый древнерусский киевский князь Игорь, муж княгини Ольги и отец Святослава Игоревича, сын Рюрика, после смерти Олега, который правил более 30 лет, носивший титул первый русский князь, согласно иностранным источникам, правящий до 945 г., действуя по просьбе Византии, чтобы ослабить влияние хазар на Юге, в 941 г. нападает на хазарский город Самкерц на Таманском полуострове (территория современной станицы Тамань Темрюкского района Краснодарского края), где проигрывает военную компанию с хазарским полководцем Песахом, и повернул свои войска против Византии.

В 943-944 гг. киевский князь Игорь с трехтысячной армией совершает поход и овладевает богатым городом Бердаа, ныне современная территория города Барда Азербайджанской Республики, бывшая столица Кавказской Албании, расположенная на притоке Куры [17, с. 576-578].

В 945 г., после убийства Игоря во время сбора дани с древлян, к власти приходит его трехлетний сын Святослав. Однако, учитывая малолетний возраст Святослава, Древнерусским государством по факту управляла его мать - княгиня Ольга до конца своей жизни, а в 959-960 гг. началось его самостоятельное правление.

Таким образом, империя Хазарского каганата Х в., занимающая торговые пути Причерноморья и на Каспии, с учетом своего географического положения, получала с купцов дань за проход в моря. Влияние Хазарского каганата угрожало выживанию Руси, что и вынудило русского князя Святослава в 964 г. готовиться к походу против хазар. Русские дружины, поднимаясь вверх по Днепру, перетащили свои суда в Оку, заручаясь поддержкой местных славянских племен, которые еще платили дань каганату до 965/969 г., вышли по Оке к Волге, по течению добрались до столицы Хазарского каганата Итиль. Удар с севера застал хазар врасплох и почти сразу взяты русскими дружинами столичные города Хазарского каганата: Семендер, Саркел и Итиль [14, с. 128-132].

В 965 г. началась решающая война между иудеями Хазарского каганата и дружинами отряда киевского князя Святослава, и в результате войны «русы» одержали победу над каганатом. На этом практически завершилось правление Хазарского каганата, с учетом потерь больше половины своих исторических земель и, соответственно, своего влияния и богатства.

Таким образом, в связи с упадком политического влияния Хазарского каганата города были разрушены, а выжившие воины Хазарского каганата укрылись на побережьях Волги. Некоторое время столица находилась в оккупации, а Хазарский правитель жил в изгнании на побережье во владениях Хорезма - Иранского Азербайджана. Только после ухода «русов» Хазарский правитель смог вернуться в цар- 
ский двор. По сообщению средневекового персидского ученого-энциклопедиста, философа Ал-Бируни, в XI в. столица Хазарского каганата Итиль лежала в развалинах [2, с. 336-352].

С другой стороны, на устойчивость Хазарского каганата также отрицательно повлияла экология, что привело к социально-экономическому кризису. Уже к середине $\mathrm{X}$ в. абсолютная отметка уровня Каспия, по данным русского географа Л. Берга, была около минус 28,5 м [4, с. 134].

Подводя итог, после падения Хазарского каганата территории также оставались под безраздельным господством народов - хазар, большая часть перешла к Волжской Булгарии, а Северный и Южный Кавказ и Средняя Азия — под влияние Персии, черноморские побережья - под влияние Османской империи. Большинство территорий каганата были объединены в составе Золотой орды. Падение Хазарского каганата сыграло особую роль в возрождении Древней Руси и Восточной Европы, опираясь на исторические факты. Хазары по природе, с учетом их внешней экономической политики, оставались земледельцами, владели большими городами по тому времени и вели интенсивную торговлю со всеми своими соседними странами через Великий шелковый путь. Изучаемый исторический период VII-X в. показывает, что противоборство Руси и Хазарского каганата определялось торговой войной.

Таким образом, обращаясь к вышеуказанным трудам отечественных историков, отметим, что именно система правления Хазарского каганата имела социальную основу, с учетом их веротерпимости к другим народам, нежели религиозный или же политический характер, в отличие от других имперских стран. Таким образом, три религии соперничали между собой с целью обратить в свою веру хазар, исповедовавших свои традиционные верования. В середине VIII в. Хазарский каганат и его окружение обратились в ислам, но в начале IX в. потомок кагана Булана ${ }^{1}$ Обадия занял второй после кагана пост в государстве и объявил государственной религией иудаизм.

\section{Литература}

1. Артамонов М. И. История хазар. Л.: Изд. Гос. Эрмитажа, 1962. 523 с.

2. Артамонов М.И. Мадьяры и печенеги. История хазар / под ред. и с примеч. Л. Н. Гумилева. Л.: Изд. Гос. Эрмитажа,1962. С. 336-352.

3. Бартольд В. В. Работы по истории и филологии тюркских и монгольских народов. Баку: Изд-во восточной лит-ры, 1968. С. 434.

4. Беленов Н. В. К этимологии этнонима «хазары» // Вестник современной науки. 2015. № 9-1(9). С. 133.

5. Ганиев Р. Т. Восточные тюрки и Китай в 630-679 гг. в Центральной Азии // Вестник Уральского отделения Российской академии наук. Наука. Общество. Человек. 2011. № 4. C. $93-108$.

6. Голден П. Достижения и перспективы хазарских исследований // Хазары. Евреи и славяне. Иерусалим; М., 2005. Т. 16. С. 27.

7. Голден П.Б. Введение в историю тюркских народов. Висбаден, 1992. С. 92.

8. Григорьев В. В. Обзор политической истории хазар // Северный архив. 1835. Т.11. C. 13.

9. Григорьев В. В. О двойственности верховной власти у хазар (1876). Изд. 3-е. М.: URSS, 2016. 106 с.: ил.

\footnotetext{
${ }^{1}$ Булан - хазарский полководец, родоначальник династии хазарских царей. Инициатор обращения хазар в иудаизм в середине VIII в.
} 
10.Гумилев Л.Н. Древние тюрки. Глава XV. Мировая война VII в. М.: Айрис-Пресс, 2009. $560 \mathrm{c}$.

11. Ибн-ал-Асир. Тарих ал-Камиль / пер. П. К. Жузе // Материалы по истории Азербайджана. Баку, 1940. С. 9.

12. Магомедов М.Г. Образование Хазарского каганата. М.: Наука, 1983. С. 181.

13. Массон М.Э. Распространение местных находок чекана династии Сасанидов на территории республик Средней Азии // История иранского государства и культуры. М., 1971. С. 220.

14.Новосельцев А.П. Города Хазарии. Хазарское государство и его роль в истории Восточной Европы и Кавказа. М.: Наука, 1990. С. 128-132.

15. Пахомов Е. А. Крупнейшие памятники Сасанидского строительства в Закавказье // Памятники истории материальной культуры. 1933. № 9, 10. С. 37-47.

16. Сказкин С. Д. История Византии: в 3 т. [АН СССР. Ин-т истории]. М.: Наука, 1967. T. 1. C. 67.

17. Якубовский А. Ю. Ибн-Мискавейх о походе русов в Бердаа в 943-944 гг. // Кузьмин А. Г. Откуда есть пошла русская земля... М.: Молодая гвардия, 1986. Т. 2. С. 576-578.

18. Плетнева С. А. Хазары и Хазарский каганат // Хазары. Евреи и славяне. Иерусалим; M., 2005. T. 16. C. 19.

19. Фахрутдинов Р. Т. Очерки по истории Волжской Булгарии. Казань: Татарское кн. изд-во, 1984. С. 117.

20.Haussig H. W. Byzantinische Qullen über Mittelasien in ihrer historischen Aussage // Prolegomena to the sources on the history of pre-Islamic Central Asia. Budapest, 1979. S. 55-56.

\title{
KHAZAR KAGANATE FROM THE CASPIAN SEA TO THE EAST (600-1000 AD)
}

\author{
Imamaddin F. Alasov \\ Research Assistant, \\ Demidov Yaroslavl State University \\ 14 Sovetskaya St., Yaroslavl 150003, Russia \\ alasov_imam@mail.ru
}

Abstract. The article characterizes the peoples of the Khazar Kaganate, taking into account Azerbaijan, which occupies a central position in geopolitics in relation to the Caspian countries on the continent. The Khazars belonged to the Turkic-speaking peoples, and in the 7 th century they created the largest trading state on the continent, pursuing primarily economic interests by subjugating the south of Russia and the east of Ukraine, the Crimean peninsula, part of Uzbekistan and Kazakhstan. The Khazar Kaganate propagated religious tolerance and justice for all the countries of the world, while Europe was much tougher on these issues. All persecuted for their beliefs rushed to the Khazar Kaganate. The Khazar Kaganate is regarded as one of the key imperial political players on the continent from 600 to $1000 \mathrm{AD}$, which exerted a strong influence over the geo-economic and geopolitical stability of all of Eurasia. The collapse of the Khazar Kaganate contributed to the development of new states, and created new geopolitical problems.

Keywords: Khazar Kaganate; Azerbaijan; Russia; the Caspian (Khazar) Sea; the countries of Central Asia.

Статья поступила в редакцию 15.05.20; одобрена после редактирования 29.05.20; принята к публикации 30.10.20. 